\title{
圧力測定・気体流量測定 $[\mathrm{I}]$
}

1. 圧力測定の基礎（重田諭吉）2. 実験室における電離真空計，マスフィルターの感度校正（荒川一郎） 3. 分圧計と分圧測定における問題点 (奥野和彦) 4. 新しい圧力測定技術（清水 肇）

\section{1. 圧力測定の基礎}

\section{1 はじめに}

ここでは, 本講座が超高真空に重点を置いていること を念頭に，超高真空領域 $\left(10^{-5} \sim 10^{-9} \mathrm{~Pa}\right)$ の全圧測定 の真空計として最も普及している熱陰極型電離真空計を 中心に，その原理・問題点を述べることにする。なお， 圧力の単位としては, パスカル : $\mathrm{Pa}(1$ 気圧 $=101323$ $\mathrm{Pa}=760$ Torr）を用いる.

\section{2 圧力測定}

圧力を評価する基本的な方法は，真空と接する液体壁 ・固体壁に加わる力による変位を直接測定することであ る. 液体壁の変位を測定する代表的な真空計として, 水 銀を利用したマノメーター・マクラウドゲージ，固体壁 の変位を測定する真空計として，ダイアフラムゲージ． 容量マノメーターなどがある。しかし，低い圧力領域で は，変位が微少になるため正確に圧力を測定することが 難しくなる，そこで，気体の性質を利用して，間接的に 圧力を評価する方法が考案されている1 つかを挙げると, 気体の粘性を利用したクヌッセンゲー ジ・スピニングローターゲージ，熱伝導を利用したピラ ニーゲージ・熱電対真空計, 気体を電離させそのイオン 電流值から圧力を評価する電離真空計, などがある. こ の中で, 手軽に超高真空領域の圧力測定に利用できるの は, 現在のところ電離真空計である.

電離真空計は, 気体分子を電子衝撃によりイオン化 し，そのイオン電流を測定し圧力を評価するが，電子衝 撃をするための電子の発生方法により, 冷陰極型と熱陰 極型に分けられる. 冷陰極型は電界放出による電子を利 用し熱陰極型はフィラメントからの熱電子を利用してい る. 冷陰極型では電界放出された電子流とその電子によ り生成されたイオン電流の和である放電電流を測定し圧 力を評価するため, 放電が持続でさる〜 $10^{-4} \mathrm{~Pa}$ 程度が 一般に測定下限とされている。一方, 熱陰極型電離真空

\footnotetext{
* Yukichi SHIGETA 横浜市立大学
}

計の測定下限は, 以下に述べるょうに, $\sim 10^{-8} \mathrm{~Pa}$ 程度 であり超高真空領域の圧力を評価できる.

\section{3 熱陰極型電離真空計}

\subsection{1 構造之原理}

熱陰極型電離真空計（イオンゲージ）には図1.1(a), (b) そ示すように，構造の違った二つのタイプがある が，基本的にはフィラメント・グリッド・コレクターか ら成る三極管であり，コレクターを接地電位とし，フィ ラメントとグリッドに正電位をかける，それぞれの電位 を $V_{\mathrm{f}} \cdot V_{g}$ とすると一般的に, $V_{\mathrm{f}}$ は数 $+\mathrm{V}, V_{g}$ は100 200 $\mathrm{V}$ である. 図1.2(a)，(b)にそれぞれの真空計の電位分 布を模式的に示す。フィラメントから放出された電子は $V_{g}$ により加速されグリッドの方向へ進んで行く．その 中でグリッドを通過した電子はコレクターに近付くが V により追い返され，フィラメントとコレクターの間 を何回か往復し，グリッドに捕らえられる。この間に， 電子は気体分子と衝突し電離により正イオンを生成す る.グリッドとコレクターの間の領域で生成された正イ オンはコレクターに捕らえられイオン電流として測定さ れる.ここで，電子の気体分子に対する電離の衝突断面 a)

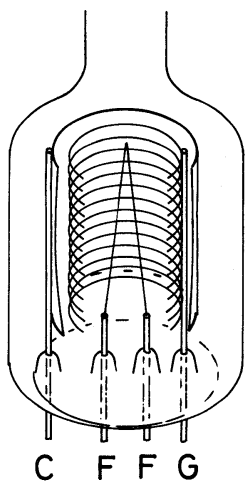

b)

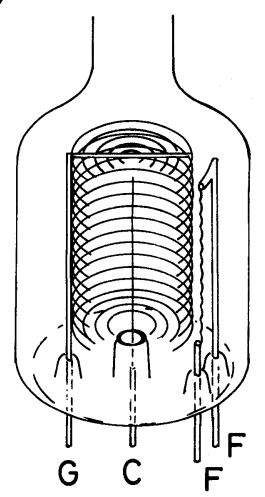

図1.1 熱陰極型電離真空計の構造. (a) 三極管型イ オンゲージ，(b) B-A ゲージ， C：イオン コレクター, $\mathrm{G}:$ グリッド, $\mathrm{F}:$ フィラメン トを示す。 
積を一定とすると, 気体分子の数（圧力）とイオン電流 は比例し，イオン電流から圧力を評価することができ る. 衝突断面積は電子の運動エネルギーと気体の種類に 依存するが，およと百数十 $\mathrm{eV}$ で最大值を示す2).

図1.1には，二つのタイプのイオンゲージを示したが， 図1.1(a) は三極管型イオンゲージで，図1.1(b) は Bayard と Alpert ${ }^{3)}$ にり改良された B-A ゲージである. 前者はフィラメントがコイル状のグリッドの内側にあ り,コレクターはグリッドの外側に円筒状に配置されて いる.このタイプのイオンゲージでは〜 $10^{-6} \mathrm{~Pa}$ 以下の 圧力を正確に評価することができなかった．その理由は 加速された電子がグリッドに衝突したときグリッドから 軟 $\mathrm{X}$ 線が生じ，この軟 X 線がコレクタ一円筒を照射し コレクターから光電子を放出させる, その光電子流が〜 $10^{-6} \mathrm{~Pa}$ の圧力におけるイオン電流と同程度となるため である。このことが Nottingham ${ }^{4)} に よ り$ 示唆され， Bayard と Alpert は軟 X 線の影響を抑えるために, 面積 の大きなコレクター円筒の代わりに図1.1(b)に示すよう な表面積の小さい細線をコレクターとし，グリッドの中 央に配置した B-A ゲージを考案した。この B-A ゲージ により〜 $10^{-8} \mathrm{~Pa}^{5)}$ の超高真空領域の測定が可能となった.

B-A ゲージでは，コレクターが細いためにイオンの捕 集効率が小さくなるよらに思えるが，グリッド内で生成 されたイオンのほとんどがコレクターに引き寄せられる ので三極管型イオンゲージにくらべ著しく小さくなると いったことはない。また，図 $1 \mathrm{~b}$ )に示した B-A ゲージ は，グリッドの上下が塞がれた形になっているが，当初 改良された時にはグリッドの上下が開いており，その後 Nottingham ${ }^{6)}$ によりグリッド内の電子を閉じ込め感度を 向上させたもので, 現在ではこのタイプが一般的となつ ている.

1.3.2 イオンゲージの感度と誤差

イオンゲージで測定されるイオン電流 $I_{\mathrm{i}}$ はフィラメ a)

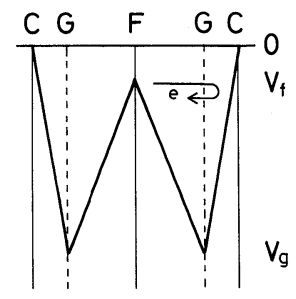

b)

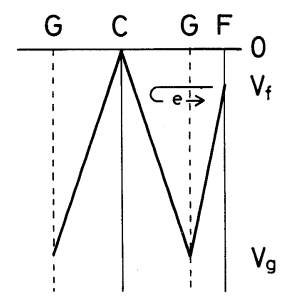

図1.2（a)三極管型イオンゲージと(b) B-A ゲージ の電位分布の模式図, 正電位を下向きにし て描いてあり，正イオンに対してはこの図 の上下をさかさまにしたものとなる。
ントから放出される電子の数（エミッション電流 $\left.I_{\mathrm{e}}\right)$. 気体分子の数 (圧力 $P$ ) . 電離の衝突断面積に比例する. 衝突断面積は, 気体の種類・電子の加速電圧に依存する が，気体の種類を特定し，フィラメントに対するグリッ ド・コレクターの電位を一定に保てば，定数と見なせる ので, イオン電流 $I_{\mathrm{i}}$ は比例定数 $g$ を用いて,

$$
\begin{aligned}
& I_{\mathrm{i}}=g P I_{\mathrm{e}} \\
& g=\frac{1}{\mathrm{P}} \frac{I_{\mathrm{i}}}{I_{\mathrm{e}}}
\end{aligned}
$$

と表せる.この比例定数 $g$ をイオンゲージの感度と呼び 単位は $\left[\mathrm{Pa}^{-1}\right]$ である.

メ一カーの仕様書には, 感度 : $0.153 \pm 0.02\left[\mathrm{~Pa}^{-1}\right]$ ま

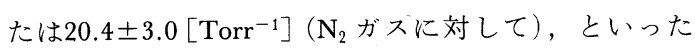
ように書かれている。.このときの䛊差は主にゲージを作 成する際の各電極の配置の工作精度からきている．すな わち, 電極配置の誤差がポテンシャル分布に影響し, 電 子衝撃によるイオン化やイオン捕獲の効率を変化させる ためである，又，仕様書の感度にこのような誤差が明記 されているのは図1.1に示したよらなガラス管球タイプ のもので, メタルフランジに B-A ゲージと同様な電極 が直接マウントされたヌードゲージでは，外壁の影響や フィラメントの取り付け位置（ユーザーが交換できるよ らになっている) などの不確定要素があるため, 誤差は 明記されていないようである，実際に Tilford ${ }^{7) か ゙ い く つ ~}$ かの三極管型イオンゲージ・B-A ゲージ・ヌードゲー ジの感度について測定した結果，それぞれのゲージに対 する感度の標準偏差は $6.7 \% \cdot 8.8 \%$ (フィラメントにト

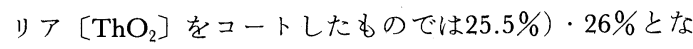
つており，製作段階でこの程度の誤差を含んでいるよう である.

われわれが実際に測定を行ら場合，それぞれの電極の 電位を維持するための電源およびイオン電流を測定する ための電流計を含んだ制御系が必要になる．市販の制御 系の精度（電源の安定性および電流増幅器の精度を含め て）は数\%程度であり，最終的な精度は B-A ゲージで 約 $20 \%$ 程度, ヌードゲージで約 $30 \%$ 程度となることがわ かる.

感度の経時変化を測定した例として, Poulter $ら^{8) や ~}$ Wood $5^{9)}$ は，三極管型イオンゲージを用いた場合，測 定時間100時間に対してー0.3〜 - 1.4\%の感度の減少が あることを示した。一方, B-A ゲージでは, 両者の結 果は異なり, Poulterらは大気に曝した後では25\%もの 変化があるのに対して, Wood らの結果は測定の間を通 して（大気に曝した後でも）士6\%の変化にとどまってい る.これらの結果を見ると, B-A ゲージでは感度の変 化には規則性がなく, ゲージの履歴など取り扱いに十分 
表1.1 種々の気体分子に対する B-A ゲージの相対 感度 $\left(\mathrm{N}_{2}\right.$ ガスを 1 とする ${ }^{10)}$

\begin{tabular}{c|r}
\hline \hline 気 & 体 \\
\hline $\mathrm{H}_{2}$ & $0.42 \sim 0.53$ \\
$\mathrm{He}$ & $0.16 \sim 0.21$ \\
$\mathrm{Ne}$ & $0.24 \sim 0.33$ \\
$\mathrm{O}_{2}$ & $0.82 \sim 0.90$ \\
$\mathrm{H}_{2} \mathrm{O}$ & $0.89 \sim 0.90$ \\
$\mathrm{~N}_{2}$ & 1.00 \\
$\mathrm{CO}$ & $0.90 \sim 1.11$ \\
$\mathrm{Ar}$ & $1.19 \sim 1.89$ \\
$\mathrm{CO}$ & $1.37 \sim 1.43$ \\
$\mathrm{Kr}$ & $1.89 \sim 1.99$ \\
$\mathrm{Xe}$ & $2.70 \sim 2.86$ \\
$\mathrm{Hg}$ & $3.37 \sim 3.70$ \\
\hline
\end{tabular}

注意を払う必要があり, 正確な圧力測定を必要とする場 合には，まめに圧力校正を行わなければならないことが わかる。

1.3.2のはじめに述べたのようにイオンゲージの感度 は, 気体の種類により電離の衝突断面積が異なるため異 なった值をとる．例として，表1.1亿種々の気体に対す

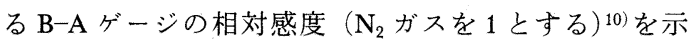
于.

このようにイオンゲージではガスの種類により感度が 変わってくる，例えば，超高真空中の残留ガスとして多 く存在する $\mathrm{H}_{2}$ に対する相対感度は約 0.5 であるから, 実際の圧力は真空計の読みの二倍とは行かないまでも高 くなっているはずである. したがって, 正確に圧力を評 価するためには質量分析計などを利用した分圧測定を行 わなくてはならない.

\subsection{3 測定上の注意}

まず，イオンゲージの清浄化（脱ガス）を十分に行ら 必要がある. 脱ガスが不十分な場合, フィラメントをは じめグリッド・コレクターからのガス放出による圧力上 昇や感度の異常を引き起こす。この感度の異常は, グリ ッド表面の吸着物質が電子衝撃により脱離イオンとなり イオン電流に影響を与えることや，コレクタ一表面の二 次電子効率の違いに起因している ${ }^{11)}$ 。また, 周囲の壁の 脱ガスも十分に行ら必要がある.

真空容器内の配線などのシールド不足や強い磁石を持 つ機器を近くで使用する場合は, 電場 ·磁場による影響 を受け感度が变化する，また，超高真空装置を用いる実 験では，電子・イオンをプローブとして測定を行う場合 が多いが，散乱電子・イオンがコレクターに入り込むと 正確な圧力の評価がでさなくなる，例えば質量分析器の

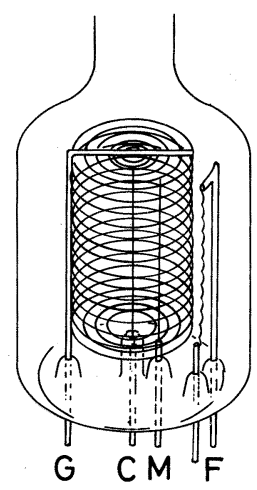

図1.3モジュレータゲージの構造, $\mathrm{M}$ ：モジュレ 一タ， C：イオンコレクター, $\mathrm{G}:$ グリッ ド, $\mathrm{F} ：$ フィラメントを示す. B-A ゲージ のグリッド内に細線できたモジュレータ M加わった構造である.

イオン化室がイオンゲージから直接見えるような場合， 質量分析器の電子がイオンゲージのコレクターに入り込 み,メーターの逆振れを起こすことさえある。このよう なことは，機器の配置を考えることである程度抑えるこ とが出来る.

イオンゲージとコントローラの継ぎ方として，数年前 までは, ワニぐちクリップによるものがよく使われてい た.いま, $2 \times 10^{-7} \mathrm{~Pa}$ の真空を感度 $0.15 \mathrm{~Pa}^{-1}$ のイオン ゲージでェミッション電流 $5 \mathrm{~mA}$ で測定したとすると, $1.5 \times 10^{-10} \mathrm{~A}$ の微少イオン電流を行らことになり，シー ルドされたコネクターと取り替えることがよいだろう。 こらすれば，数百 $\mathrm{V} の$ 電位のかかった電極にらっかり 触れてしまうような危険も避けられる.

1.3.4 変調法による測定（モジュレータゲージ）

1.3.1で述べたように，B-A ゲージにおいても軟 X 線 の影響により測定限界が $10^{-8} \mathrm{~Pa}$ 程度に抑えられてしま っている．Redhead ${ }^{12)}$ は図1.3のようにグリッドの中に コレクターとは別の細線（モジュレータ：M）を挿入 し，そのモジュレータにグリッド電位 $V_{g}$ とコレクター 電位 $V_{\mathrm{c}}$ (接地電位) を交互に与え, 真のイオン電流 $I_{\mathrm{io}}$ だけを評価する変調法を考案した。いま，軟 X 線によ る光電子流を残留電流として $I_{\mathrm{r}}$ とかくと， $\mathrm{M}$ が $V_{g}$ の時 のコレクター電流 $I_{\mathrm{i} g}$ は,

$$
I_{\mathrm{i} g}=I_{\mathrm{io}}+I_{\mathrm{r}}
$$

となり， $\mathrm{M}$ が $V_{\mathrm{c}}$ の時にはモジュレータにある程度イオ ン電流が流れるため, その時のコレクタ一電流 $I_{\mathrm{ic}}$ は, $\alpha(0<\alpha<1)$ を定数として,

$$
I_{\mathrm{ic}}=\alpha I_{\mathrm{io}}+I_{\mathrm{r}}
$$

と表される．この定数 $\alpha$ は電極の機械的配置によって 
決まると考えてよいので, $I_{\mathrm{r}} \ll I_{\mathrm{io}}$ を満足する圧力領域 $\left.\sim 10^{-5} \mathrm{~Pa}\right)$ で $\alpha \sim I_{\text {ic }} / I_{\mathrm{i} g}$ を測定して拈けば，真のイオン 電流 $I_{\text {io }}$,

$$
I_{\mathrm{io}}=\frac{I_{i g}-I_{\mathrm{ic}}}{(1-\alpha)}
$$

となる。（1）式より真空計の読みは，エミッション電流 を一定にしておけば $I_{\mathrm{i} g} \cdot I_{\mathrm{ic}}$ に比例しているので，それぞ れの場合の真空計の読みを $P_{g} \cdot P_{\mathrm{c}}$ とすると, 真の圧力 $P_{0}$ は,

$$
P_{0}=\frac{P_{g}-P_{\mathrm{c}}}{(1-\alpha)}
$$

によって与えられる。いま， $\alpha=0.7$ と,$I_{\mathrm{i} g}$ と $I_{\mathrm{ic}}$ の変 化が $I_{\mathrm{i} g}$ の $10 \%$ まで正確に測定できるとすれば， $0.9\left(I_{\mathrm{io}}\right.$ $\left.+I_{\mathrm{r}}\right)=\left(0.7 I_{\mathrm{io}}+I_{\mathrm{r}}\right)$ となり, この方法により残留電流 $I_{\mathrm{r}}$ の半分の值までの真のイオン電流が求められることにな る、ただし，モジュレータの電位を変えても残留電流は 変化しないといら仮定が入っている，実際には，モジュ レータがグリッド電位のとさにモジュレータからの軟 $\mathrm{X}$ 線による光電子流が残留電流に加わるため, 残留電 流がモジュレータの電位により15\%程度変化することが Appelt ${ }^{13)}$ により示されている.この変化を補正する方法 の一つとして, 辻ら ${ }^{14)}$ の行った負電位法がある.この方 法は，モジュレータにー100〜 - $150 \mathrm{~V}$ の負電位をかけ て，その時のコレクター電流 $I_{\text {in }}$ を測定する。この場合 のコレクター電流 $I_{\text {in }}$ は,

$$
I_{\mathrm{in}}=\beta I_{\mathrm{io}}+I_{\mathrm{r}}
$$

と表される．この $\beta$ の值は， $\alpha$ を測定したと同様に $I_{\mathrm{r}} \ll$ $I_{\text {io }}$ を満足する条件で測定できる. 真のイオン電流は,

$$
I_{\mathrm{io}}=\frac{I_{\mathrm{ic}}-I_{\mathrm{in}}}{(\alpha-\beta)}
$$

によって求められる.この方法は, モジュレータをコレ クター電位または負電位にしているために, モジュレー タからの軟 X 線の影響を無視できる。この方法におい ても， $\alpha=0.7, \beta=0.4$ として $I_{\text {ic }}$ と $I_{\text {in }}$ の変化が $10 \%$ をで 測定できたとすると, 残留電流の約半分の真のイオン電 流が測定できる.

これらの変調法では， $\alpha \cdot \beta$ の值を比較的高い圧力で 正確に測定しておく必要があるが，1.3.3で述べたよう にイオンゲージの表面が污机ていると, 感度の異常を示 すことがあるため，イオンゲージを十分に脱ガスしてお く必要がある．そこで, $10^{-7} \sim 10^{-8} \mathrm{~Pa}$ 程度の圧力で脱 ガスを十分行い，不活性ガスまたは $\mathrm{N}_{2}$ ガスを $10^{-5} \mathrm{~Pa}$ 程度まで導入して $\alpha \cdot \beta$ の值を測定すると言った方法が 理想的であろう。

\section{4 その他の超高真空用真空計}

ここで述べた熱陰極型電離真空計を用いてょり低い圧

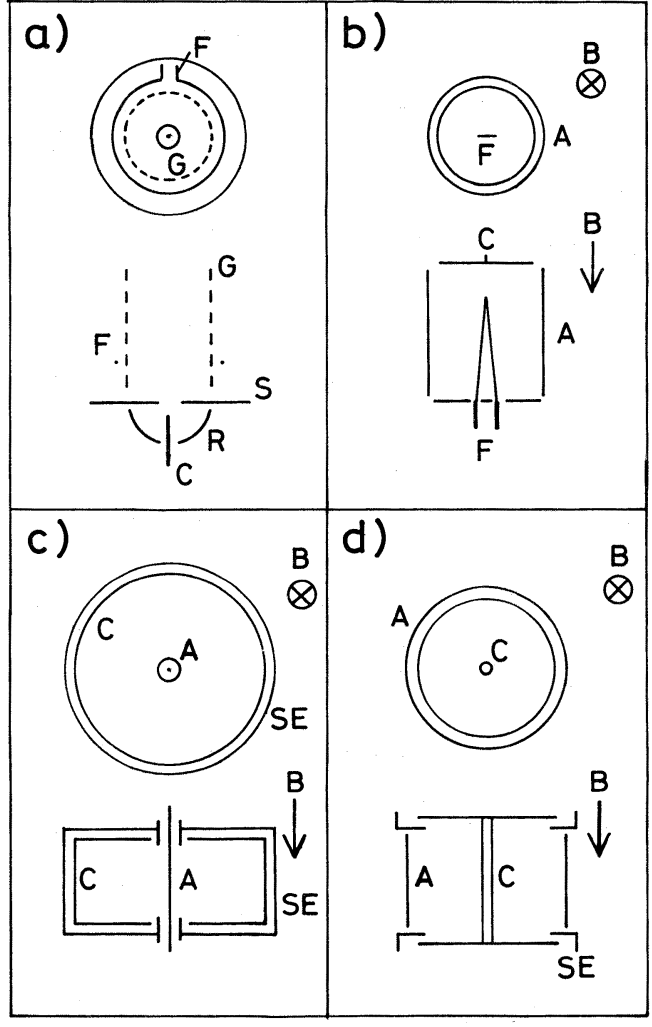

図1.4 超高真空用に考案された電離真空計の模式 図.（a）extractor gauge，（b）熱陰極型マグ ネトロンゲージ，（c)逆転型マグネトロン ゲージ，(d)マグネトロンゲージ, F : フィ ラメント, $\mathrm{G}:$ グリッド, $\mathrm{S} ：$ スリット, $\mathrm{C}:$ イオンコレクター, $\mathrm{R}:$ リペラー, $\mathrm{A}$ : アノード, $\mathrm{SE}:$ 補助電極, $\mathrm{B}:$ 磁場の方向 を示す.

力 ( $10^{-9} \mathrm{~Pa}$ 以下 $)$ を評価する場合, 本質的な問題点 として, 軟X線による残留電流, グリッドからのイオ ン脱離によるイオン電流の増加, 熱陰極からの脱ガスに よる圧力上昇などがある．これらの問題点を克服するた めにいくつかのタイプの真空計が考案されている5,15).

図1.4にその一部を模式的に示す. 図中の (a)はグリッド からの軟 X 線の影響を避けるため, グリッドの外にコ レクターを置き，スリットSを通してイイン電流を測 定するもので“extractor gauge”と呼ばれ，軟 X 線によ る測定限界は $10^{-11} \mathrm{~Pa}$ 以下と報告されている ${ }^{16)}$.このタ イプの真空計は, 感度が B-A ゲージに較べ 1 桁程度小 さいが二次電子増倍管 (SEM) を備えた改良型の測定 限界は $10^{-13} \mathrm{~Pa}$ 程度と見積られている17)。（b）は円筒状

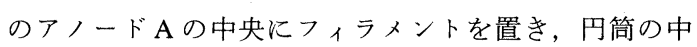
心軸に平行に磁場 B をかけたもので熱陰極型マグネト 
ロンゲージまたは Lafferty ゲージと呼ばれている18,19). 中央のフィラメントから出た電子は, 磁場 Bにより旋 回運動しアノードに到達するまでに非常に長い軌道を運 動する，このためイオンを生成する確率が増大し感度 $g$ が〜 $10^{4} \mathrm{~Pa}^{-1}$ と非常に高くなる. したがって，ェミッシ ョン電流が $10^{-9} \sim 10^{-6} \mathrm{~A}$ といら低い值で使用でき, 軟 $\mathrm{X}$ 線の発生を抑えることができる。このゲージの軟 X 線による測定下限は〜 $10^{-13} \mathrm{~Pa}$ と推定され ${ }^{19)}$, コレクタ 一部に SEM を取り付けた改良型では〜 $10^{-16} \mathrm{~Pa}$ と推定 されている20).ただし，このゲージを用いて実際に測定 されている最低圧力は〜 $10^{-11} \mathrm{~Pa}$ である.

ガス放出源であるフィラメントを使用しない冷陰極型 の超高真空用真空計の例として, 図1.4(c), (d)に示す逆 転型マグネトロンゲージ21,22) とマグネトロンゲージ23)が ある. 冷陰極型の真空計は, $10^{-5} \mathrm{~Pa}$ 以下の圧力で放電 を開始するまでの時間が長くなるとか，放電を維持する ことができないと言われてきたが，Hobson と Redhead $^{21)}$ により考案された超高真空用の逆転型マグネ トロンダージでは放電開始の遅れはあるものの圧力が〜 $10^{-10} \mathrm{~Pa}$ でも放電を維持させることができ, 超高真空領 域の真空計として利用できることを示した，逆転型マグ ネトロンゲージの各電極の電位はコレクターと補助電極 $\mathrm{SE}$ をアース電位としアノードを 5〜10 kVとしている. この逆転型マグネトロンゲージの問題点はイオン電流 $I_{\mathrm{i}}$ と圧力 $P$ の関係が, 測定を行った $10^{-2} \mathrm{~Pa} か ら 10^{-9} \mathrm{~Pa}$ の圧力範囲で, 単純な比例関係ではなく,

$$
I_{\mathrm{i}} \propto P^{1.2}
$$

によって表されるといらことであった24)．これに対して 中央に陽極を配置し，圧力が〜 $10^{-8} \mathrm{~Pa}$ までイオン電流 と圧力の直線性が保たれ，この圧力以下で非直線性を示 すマグネトロンゲージ（図1.4(d)）をRedheadが開発 した。この非直線性は，その後の測定により〜 10-10 $\mathrm{Pa}$ の圧力まで直線性が保たれている報告例がある25,26).こ の冷陰極型真空計の測定下限は, コレクターが強い電場 にさらされている部分からり電子の電界放出の量とイオ ン電流の大小関係で決まると考えられ，そのために超高 真空用のものには補助電極 SEを置きコレクターが陽極 の電場に直接さらされないよらに工夫されているが，そ の量に関しては, 電極の微妙な配置に強く影響されるた めか議論が成されていない。したがって, 測定下限は実 測されている $10^{-10} \mathrm{~Pa}$ 以下で放電が維持できる圧力とい らことになるが, その領域でイオン電流と圧力の関係に 直線性が保たれている保証はない。冷陰極電離真空計の 問題点としては，ポンプ作用が大きく，排気速度にする と B-A ゲージの標準的な值に較べ $2 \sim 3$ 桁大きい $10^{-1} \sim$ 数 $l / \mathrm{s}$ 程度あること ${ }^{5)}$, 電極表面の清浄度の違いによる
放電電流・イオン電流への影響が解明されていないこ と, また, 磁場の影響を受けやすい実験装置への使用は できない,などが挙げられる。

この他にも, 放電のトリガーとして熱陰極27)を持つ冷 陰極型, また紫外線による光電子を増倍して電子源とし たもの 28,29)などが考案されている.

\section{5 むすび}

超高真空領域の圧力の評価法として, 最も普及してい る B-A ゲージを中心にその問題点などを述べてきた. 一方, 最近の真空技術の進歩にともない, B-A ゲージ の測定限界である $10^{-9} \mathrm{~Pa}$ 以下の真空下で種々の実験が 比較的手軽に行われるようになっている，そこで，BA ゲージに変わる真空計の普及が待たれていると言えよ $\zeta$.

\section{謝 辞}

本稿を書くにあたり，有意義な御意見を頂いた横浜市 立大学 馬来国唱教授に感謝致します。

\section{[文献]}

1）詳しくは, 熊谷寛夫, 富永五郎, 辻 泰, 堀越源 一：「真空の物理と応用」物理学選書11（1970）裳華 房などを参照されたい。

2) J. T. Tate and R. T. Smith: Phys. Rev. 39 (1932) 270.

3) R. T. Bayard and D. Alpert: Rev. Sci. Instr. 21 (1950) 571.

4) W. B. Nottingham: 7th Ann. Conf. on Phys. Electron., M.I.T., 1947.

5）林 主税，小宮宗治：「超高真空」真空技術講座第 6 巻（1964）日刊工業新聞社. ただし, 絶版となっ ている.

6) W. B. Nottingham: Trans. 1954 Vacuum Symp., Comm. Vacuum Techniques, Boston, 1955, p. 76.

7) C. R. Tilford: J. Vac. Sci. Technol. A3 (1985) 546.

8) K. F. Poulter and C. M. Sutton: Vacuum 31 (1981) 147.

9) S. D. Wood and C. R. Tilford: J. Vac. Sci. Technol. A3 (1985) 542.

10) T. A. Flain and P. D. Ownby: J. Vac. Sci. Technol. 8 (1971) 661.

11) J. W. Ackley, G. F. Lothrop and W. R. Wheeler: Trans. 9th National Vacuum Symp. (MacMillan, New York, 1962), p. 452.

12) P. A. Redhead: Rev. Sci. Instr. 31 (1960) 343.

13) G. Appelt: Vakuum-Tech. 11 (1962) 174.

14）辻 泰, 岡田 怜, 金 文沢 : 真空12 (1969) 18.

15) P. A. Redhead: J. Vac. Sci. Technol. A2 (1984) 132.

16) P. A. Redhead: J. Vac. Sci. Technol. 3 (1966) 173.

17) D. Blachshmidt: J. Vac. Sci. Technol. 10 (1973) 376.

18) G. K. T. Conn and H. N. Daglish: J. Sci. Instrum. 31 (1954) 412.

19) J. M. Lafferty: J. Appl. Phys. 32 (1961) 424. 
20) J. M. Lafferty: Trans. 9th National Vacuum Symp. (MacMillan, New York, 1962) 438.

21) A. H. Beck and A. D. Brisbane: Vacuum 2 (1952) 137.

22) J. P. Hobson and P. A. Redhead: Can. J. Phys. 36 (1958) 271.

23) P. A. Redhead: Can. J. Phys. 37 (1959) 1260.

24) P. A. Redhead: Can. J. Phys. 36 (1958) 255.

25) G. A. Nichiporovich: Instrum. Exp. Tech. No. 6, (1967) 1440.
26) G. A. Nichiporovich and I. F. Khanina: Proc. 4th Int. Vacuum Congress (institute of Physcs, London, 1968), p. 666.

27) J. R. Young and F. P. Hession: Trans. 10th National Vacuum Symp., (MacMillan, London, 1963), p. 234.

28) H. Riemersma, R. E. Fox and W. J. Lange: Rev. Sci. Instr. 32 (1961) 218.

29) H. Riemersma, R. E. Fox and W. J. Lange: Trans. 7th National Vacuum Symp. (Pergamon, New York, 1961), p. 92.

\section{圧力測定 $\cdot$ 気体流量測定}

\section{2. 実験室における電離真空計・マスフィル ターの感度校正}

\section{1 はじめに}

高真空 (HV), 超高真空 (UHV) 領域での気体の圧 力の測定には, 電離真空計と四極子型質量分析計（マス ・フィルター）が広く用いられていますＵUHV 領域で 一般的に使われている Bayard-Alpert 型の電離真空計の 確度は，扮拈まかにいって 0.5 析程度でしょう。三極 管型の電離真空計では，も5少し良い確度が得られるか も知れません。、ス・フィルタ一の出力信号から, 直接 気体の圧力（分圧）を読及とろらとすれば，さらに大き な誤差が伴います．確かに“真空度”のモニターとして 電離真空計を使うのならば，あるい慎空装置のリーク 試験とか残留ガス分析による “真空の質”のモニターと してマス・フィルターを使らのならば，この程度の確度 で問題はないでしょう。しかし，実駼等において気体の “圧力 (密度)”，“量”を測定しょうとする時に，より高 い確度が必要になることはしばしばあります。種々の物 理量の測定の中で, この領域（压力 $p \lessgtr 10^{-4} \mathrm{~Pa}$ ) の圧 力測定はもっとも誤差の大きなものでしょら。

電離真空計は, 基本的に熱電子源（エレクトロン・ソ ース,フィラメント), 集電子電極（エレクトロン・コ レクター, グリッド), 集イオン電極（イオン・コレク ター）の 3 種の電極で構成されています，その感度はこ れらの電極の構造（形状, 位置, 大きさ）で決められる 空間の電位分布に依存しており，製造工程で起こりらる 形状等のわずかの違いが大さな感度の変化をもたらしま す。したがって個々の測定子に対する感度の校正をした のでない限り，メーカーの公称値と手にしている測定子 の真の感度は一致していないのが普通です，その偏差の 程度もメーカーによって大小あるようです。
器壁など，測定子近傍の空間の電位に影響を与えるも のとの位置関係も感度に影響します。したがって, ヌー ド型の測定子は，とりつけ方でも大きな感度の差が現わ れます。また一つの測定子でも，使用している間に電極 の変形, 電極, 器壁への污れの付着のため感度が変化し ます。

以上が，電離真空計による圧力測定の確度を低くして いる主な原因です。したがって正確な測定を行ならため には，使用する真空装置に測定子をとりつけた状態で校 正をしなければなりません。しかも，経時変化により生 ずる誤差を補償するためには，随時校正を行なら必要が あります。

著者は，一連の実験の中で $\mathrm{H}_{2}, \mathrm{He}, \mathrm{Ne}, \mathrm{Ar}, \mathrm{Kr}, \mathrm{Xe}$, $\mathrm{N}_{2}, \mathrm{CO}_{2}, \mathrm{CH}_{4}$ 等の気体に対する, $\mathrm{B}-\mathrm{A}$ 型電離真空計の 感度係数の校正を行ってきました，種々の気体に対する 比感度係数（ $\mathrm{N}_{2}$ に対する値を 1 とした時の相対值）を $\pm 1 \sim 5 \%$ の確度で測定してみると，それらの值は，真空 技術の教科書，ハンドブックにあるどの表とも一致しま せんでしたし，同一メ一カの同型の測定子でも，比感度 係数の相対的な関係は個々の測定子によって違いまし た、このような点から，実験装置における校正の必要性 を強く感じています。

マス・フィルターでは, ピークの形状等, 感度に大き な影響を持つ種々の微調整を，実験の度に正確に同じ点 に設定するのも非現実的ですし, 電源の不安定性と二次 電子増倍管の増幅率の変動は，それ以上に大きな誤差の 原因になります。いずれにしても電離真空計と同程度の 再現性を得るためには校正が不可欠であり，その校正も 電離真空計の場合よりひんぱんに行ら必要があります。

電離真空計とマス・フィルターの測定誤差の原因に は，他にも測定子自身からの気体放出とその逆の排気作 用がありますが，ここではそれらにはふれません。

\section{2 標準となる圧力計}

校正そ行らためには圧ノひ標準が必要です，圧力標準 を得るためには，信頼できる別の圧力計を使ら方法と， 
圧力を決定する何らかの物理現象（蒸気圧など．付録 1 参照）を利用する方法があります，電離真空計の校正を 行ら圧力領域で後者に相当する現実的な方法は見あたり ません，標準となり得る圧力計として，いくつかのもの があげられます。水銀マノメーターと McLeod ゲージ は，圧力の一次的な標準として最も基本的なものです が，操作性を考光ると実用的ではありません，また水銀 による実験装置の污染の心配があるので好ましくありま せん．

石英ブルドン管圧力計（Texas Instrument 社製など）, スピニング・ローター・ゲージ (Leybold-Heraeus 社製,

$\mathrm{MKS}$ 社製），隔膜圧力計（MKS 社製 Baratron, Data Metrics 社製 Barocel など）が，ここでの目的には標準 圧力計として使うことが可能です。ブルドン管圧力計 は, 数十 $\mathrm{kPa}$ (数百 Torr) 程度のフルスケールに対し, その $10^{-2} \sim 10^{-3} \%$ の分解能を持っています。確度も高く 安定性も良いのですが，実験使うには操作がわずらわ しく, UHV 装置に直接つなげるのは, ベーキングがで きないこと，通常わずかのリークがあることなどから少 々抵抗があります、スピニング・ローター・ゲージの測 定領域は $1 \sim 10^{-5} \mathrm{~Pa}\left(10^{-2} \sim 10^{-7} \mathrm{Torr}\right)$ で, 電離真空 計の感度が一定と見なせる圧力領域 $10^{-2} \sim 10^{-3} \mathrm{~Pa}$ 以下 と重なっているので, 直接比較校正することが可能で す. 隔膜圧力計は, フルスケールが $10^{2} \sim 10^{5} \mathrm{~Pa}\left(1 \sim 10^{3}\right.$ Torr), 分解能がその $10^{-2} \sim 10^{-3} \%$ で, 測定範囲, 精度 などは実験の目的に応じて種々の形式のものから選択で きます。

測定可能な圧力範囲を見ると，校正だけを目的とする ならばスピニング・ローター・ゲージが適しているとい えます。しかし, 実験の中で気体の導入量, 流量の測定 を行う必要があるならば，隔膜圧力計が使いやすく，広 い測定範囲から選択でき，より沉用性があります。価 格，入手し易さなどの点でも有利でしょう，以下は，著 者が隔膜圧力計を標準として行った電離真空計の校正の 経験を基にしています。

\section{3 電離真空計の校正}

隔膜圧力計の測定下限（分解能）は $10^{-3} \mathrm{~Pa}$ からせい ぜい $10^{-4} \mathrm{~Pa}$ です。一方, 電離真空計が圧力に対して線 形性を保っているのは $10^{-2} \sim 10^{-3} \mathrm{~Pa}$ 以下の領域ですか ら, 両者を直接比較することは不可能ではないにして も，校正といら目的にかなら精度・確度は得られないで しょ5.

比較する圧力領域を間接的に拡張する方法には, 流量 法之膨張法の二つがあります，流量法は図2.1亿示すよ らに, コンダクタンス $C_{1}, C_{2}$ (あるいは実効的な排気速 度 $S$ ）のオリフィスに流量 $Q$ の気体を流し, 校正した

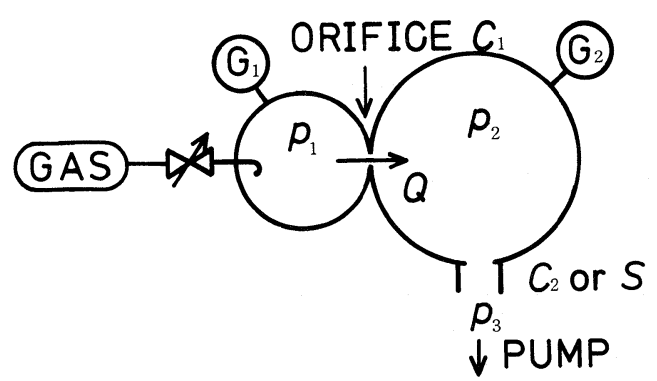

図2.1＼cjkstart流量法の模式図

いゲージ $\mathrm{G}_{2}$ のある空間での圧力 $p_{2}$ を得る方法です．標 準圧力計 $G_{1}$ を使って測定した圧力 $p_{1}$ から，式(1)によ って $p_{2}$ を求めます．ここで $p_{1} \gg p_{2} \gg p_{3}$ となるよらに $C_{1}$, $C_{2}$ 等を決めます.

$Q=\left(p_{1}-p_{2}\right) C_{1}=\left(p_{2}-p_{3}\right) C_{2}$, または $=p_{2} S$

しかしこの方法で問題になるのは， $C_{1}, C_{2}, S$ の值の正 確な測定, 圧力領域が分子流と粘性流の領域にまたがっ た時のコンダクタンスの補正, 気体の流れによって生じ る圧力の非均一性, 非等方性の影響です。これらは，才 リフィスと容器の幾何学的形状を工夫することによって 解決できます，実際，そのように設計された装置が圧力 計の校正に使われています。しかし，校正自体が目的で ない実験では，この条件を満足するように装置を設計す ることは，必ずしも可能ではありません（簡単な流量 計については付録 2 を参考にしてください.)

流量法が動的な方法であるのに対し，膨張法は静的な 方法です。図2.2のような装置で, 標準圧力計 $\mathrm{G}_{1}$ を備 党た容積 $V_{1}$ の容器に気体を満たし，バルブを開いて $V_{2}$ に導入した時，導入前後でのそれぞれの圧力， $p_{1 \mathrm{i}}, p_{1 \mathrm{f}}$, $p_{2 i}, p_{2 \mathrm{f}}$ は式(2)の関係にあります。

$$
\left(p_{1 \mathrm{i}}-p_{1 \mathrm{f}}\right) V_{1}=\left(p_{2 \mathrm{f}}-p_{2 \mathrm{i}}\right) V_{2}
$$

校正したい圧力計 $\mathrm{G}_{2}$ の示すべき圧力は， $V_{1}$ と $V_{2}$ が わかっていれば計算できます。比 $V_{2} / V_{1} か ゙ 100 〜 1000$ と なるよらにすれば，一度の膨張で隔膜圧力計と電離真空 計の測定領域を重ねることができます。必要ならば膨張 を数回行って範囲を拡げるとともに，圧力計の線形性の 確認もできます。

単に圧力計の校正だけが目的ならば， $V_{2}, V_{1}$ の比さ光 知れば充分です。式 (2)で $p_{1 \mathrm{f}}=p_{2 \mathrm{f}} \gg p_{2 \mathrm{i}}$ の条件を満足すれ ば, 比は式(3)で与党られ，標準圧ノ計だけと用いて測 定できます。

$$
\frac{V_{2}}{V_{1}}=\frac{p_{1 \mathrm{i}}}{p_{1 \mathrm{f}}}-1
$$

実験では, 図2.2の系の $V_{1}$ 側は, 主真空容器 $V_{2}$ への 気体導入系となります。気体の量の測定のためには体積 


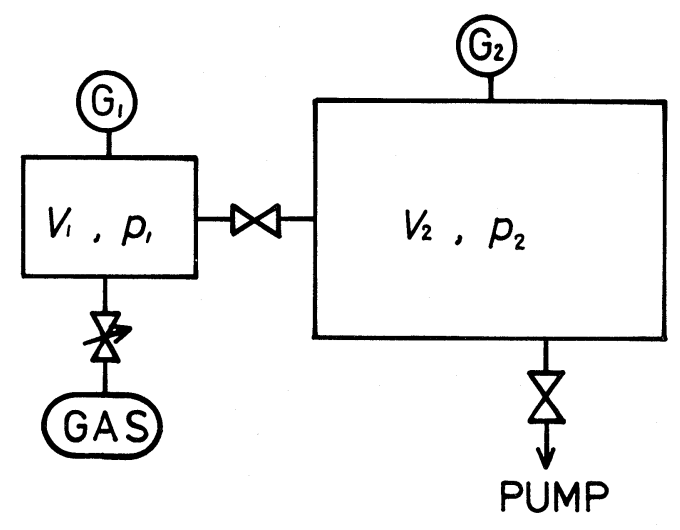

図2.2 膨張法の模式図

の絶対值が必要です，最も簡単な方法は，水, アルコー ル等を満たして内容積 $V_{\mathrm{r}}$ を測定した容器を， $V_{1}$ にけ た時とつけない時で式(3)の比を測り， $V_{1}$ と $V_{2}$ を求め る方法です。すなわち, 式(3)と式(4)の連立方程式を解 けばよいわけです。

$$
\frac{V_{2}}{V_{1}+V_{\mathrm{r}}}=\frac{p_{1 \mathrm{i}}^{\prime}}{p_{1 \mathrm{f}}^{\prime}}-1
$$

この方法では， $V_{\mathrm{f}}$ と $V_{\mathrm{r}}$ の間にバルブを設ける必要もあ りませんし，死容積による䛊差もありません。

著者の使用していた B-A 型の測定子の感度係数の膨 張法による実測值を表2.1亿示します．前述のように， これらの值はメーカーから提供されている值とも違いま すし，相対的な関係も発表されている種々の值と一致し ていません. 圧力 $10^{-3} \mathrm{~Pa} \sim 10^{-4} \mathrm{~Pa}$ の領域で行った校正 值の分散と数週間内での再現性は, 希ガスではいずれも 士2\%程度に収まりました。この校正結果がどの程度の 確度を持っているか確かめてはいませんが，校正した測 定子を用いて行った実験の結果等から逆に評価すると,

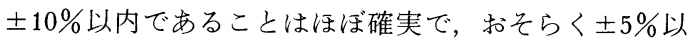
内には収まっていると思われます。

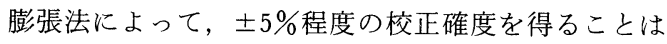
比較的容易ですが， $\pm 1 \%$ の確度を保証することは困難 でしょう。主な原因は，校正時の測定子の排気作用と気 体放出です. 特に, $\mathrm{H}_{2}, \mathrm{CO}_{2}$ 等の活性気体では, この効 果が大きく， $\pm 5 \%$ の確度を得るのも難かしくなります。 これらの気体では, 測定子の排気作用の影響が少ない流 量法を使った方が良い結果が得られると思われます。確 度の限界が上記の原因で $1 \%$ 程度に押えられてしまい ますので, 他の誤差要因, 例えば体積測定に対する配慮 は楽になります。もちろん, 気体は完全気体として扱え ます. 注意が必要なのは, 真空容器の温度の不均一に対 する補正, 測定子の容積変化などでしょう. 隔膜圧力計
表2.1 電離真空計の感度係数の実測例

\begin{tabular}{lcc}
\hline \hline 気体 & $\begin{array}{c}\text { 感 度 } \\
\left(\mathrm{Pa}^{-1}\right)\end{array}$ & $\begin{array}{c}\text { 係 } \\
\text { 数 } \\
\left(\text { Torr }^{-1}\right)\end{array}$ \\
\hline $\mathrm{He}$ & $1.84 \times 10^{-2}$ & 1.45 \\
$\mathrm{Ar}$ & $1.62 \times 10^{-1}$ & 21.5 \\
$\mathrm{Kr}$ & $1.89 \times 10^{-1}$ & 25.2 \\
$\mathrm{Xe}$ & $2.73 \times 10^{-1}$ & 36.3 \\
$\mathrm{H}_{2}$ & $4.4 \times 10^{-2}$ & 5.9 \\
$\mathrm{~N}_{2}$ & $14.2 \times 10^{-1}$ & 14.2 \\
$\mathrm{CH}_{4}$ & $1.71 \times 10^{-1}$ & 22.7 \\
\hline
\end{tabular}

は, 圧力によって $1 \mathrm{~cm}^{3}$ 以上の変化が起こります.

\section{4 マスフィルターの校正}

マスフィルターの感度は, 数時間の実験の間にも時々 刻々変化します。これは, 主として二次電子増倍管 (SEM) の増幅率変化によるものです. 特に $\mathrm{H}_{2}$ 雲囲気 中では, SEMの劣化が著しく, 例えば著者の経験で は, $10^{-2} \sim 10^{-3} \mathrm{~Pa}$ の圧力の $\mathrm{H}_{2}$ への短時間（ $\lesssim 10$ 秒） の露出の繰り返し（10～30回）で一桁以上の感度の低下 が見られました。、マフィルターに対しても膨張法によ る校正は可能ですが，実験の最中にひんぱんに校正が必 要な時には実用的ではありません．

実用的な方法は, 校正された電離真空計との相互比較 です。もちろん電離真空計は全圧計なので, 単純に比較 はできません，測定しょうとする気体の分圧だけが変化 するよらな状態で, 両方の圧力計の出力信号の変化分の 比から感度を求めます. 試料気体を装置内に導入する時 などに, 両出力をレコーダー・チャートまたはコンピュ 一タ一等に記録しておけば, 広い圧力範囲で校正值を得 られます．この方法で $\pm 10 〜 30 \%$ の確度は可能です．

混合気体を用いる場合や同時に複数種の成分の分圧の 変化が起こる場合には, この方法は使えません. 成分比 のわかっている試料気体に対して, あらかじめ膨張法で 全圧に対する電離真空計の感度係数を校正しておくなど の工夫が必要です。

\section{付録 1}

$\lceil\mathrm{UHV} 」 と い ら$ 本講座の領域からは外れますが, ここ で述べた校正法の基準になっている，隔膜圧力計など $10^{2} \sim 10^{5} \mathrm{~Pa}\left(1 \sim 10^{3}\right.$ Torr $)$ の領域の圧力計の校正につ いて述べます。メーカーの仕様によれば, Baratron 等 の圧力計を $\pm 1 \%$ の許容誤差で使らのならば，長期にわ たって再校正の必要はほとんどないと言えます。しか し, 測定子の使用法の誤りなどの事故が原因で, 指示值 に疑いを持つよらになることは度々あります。メーカー へ再校正を依頼するのが確実な方法ですが, 時間, 費用 の問題，あるいはメーカーの校正さえも信用できないと 
いら場合もあるでしょう。

水銀マノメーターとの相互比較を行学ば, $\pm 1 \%$ 以内 の確度を得るのは容易です。しかし水銀による污染が問 題になります、実験室で測定子を装置に取り着けたまま で校正するためには, 種々の物質の蒸気圧を参照值にす る方法があります，真空への影響を考慮して，なるべく 単純な炭化水素系の液体（これにしてもあまり好ましく はありません), 水などの純度の高いものを用います。 ガラス等のチューブに入れて真空系に取り着け, さらに 真空中で脱ガス, 蒸留してから使用します. 温度は, 安 定性の高さを考えると氷点を用いるのが手軽で確実で す。水ならば三重点を使らことができ，平衡蒸気圧は $612.1 \mathrm{~Pa}$ (4.592 Torr) です。種々の物質の蒸気圧は $\pm 0.1 \%$ 以内確度で得られています.しかし, 真空容 器内壁への吸着, 凝縮の影響が大きいので, 校正値の硬 度は土0.5\%程度になるでしょう。

\section{付録 2}

オリフィス法による流量測定で問題になることは, 中 間流領域の取扱いの難しさとそこから生じる測定誤差で す。小さな流量を測る場合には, 分子流条件が常に成り 立つよらにオリフィスを設計して，この困難を避けられ ます。

オリフィスの直径 $D$ と気体分子の平均自由行程 $\lambda$ が, $D \leq \lambda$ の関係にあれば, 分子流条件は充分満たされま
す。気体の圧力 $p$ とは $\lambda \propto 1 / p$ の関係にあるので， $D$ を与えれば分子流条件のための $p$ の上限 $p_{\max }$ が決まり ます，分子流条件下では, オリフィスのコンダクタンス $C$ は, $p$ によらず一定で,

$$
C=\frac{1}{4} \cdot \frac{\pi D^{2}}{4} \cdot \sqrt{\frac{8 R T}{\pi M}}
$$

$(R:$ 気体定数, $T:$ 温度, $M:$ 分子量 $)$ となります。オリフィスを通る流量 $Q$ は，上・下流の 圧力 $p, p^{\prime}$ (多くの場合 $\left.p \gg p^{\prime}\right)$ から,

$$
Q=C\left(p-p^{\prime}\right) \sim C p
$$

として得られます。この方法で測れる最大流量 $Q_{\text {max }}$ は, $Q_{\text {max }}=C p_{\max }$ です。例えば $\mathrm{Ar}$ に対して $D=0.3 \mathrm{~mm}$ のオリフィスを使うと, 室温で入〜0.3 $\mathrm{mm}$ となる圧力 $p_{\max }$ は26 Pa (0.2 Torr), $C=2 \times 10^{-6} \mathrm{~m}^{3} / \mathrm{s}, \quad Q_{\max } \sim 5 \times$ $10^{-5} \mathrm{~Pa} \mathrm{~m}^{3} / \mathrm{s}\left(4 \times 10^{-4}\right.$ Torr $\left.l / \mathrm{s}\right)$ となります.

上に示した $Q_{\max }$ はオリフィスー個あたりの流量の上 限ですから, 実験に用いる気体の種類, 必要とする流量 範囲, 圧力計の測定領域に応じて, オリフィスの数と直 径を決めることができます。オリフィスは，アルミニウ ム箔に穴をあけて自作する他，電子顕微鏡用に市販され ている絞り（数 $10 \mu \mathrm{m} ）$ が使えます。コンダクタンス は,オリフィスを通して気体をにがした時の圧力の降下 曲線から求めるのが簡単です。この方法での流量の測定 確度は， $\pm 5 \%$ からせいぜい $1 \%$ が限度でしょら。 